\title{
PELAJARAN SENI BUDAYA PADA PELAKSANAAN PPL MASA PANDEMI COVID-19 DI SMP 35 NEGERI PALEMBANG
}

\author{
Muhsin Ilhaq $^{1)}$, Yenny Fadhilah ${ }^{2)}$ \\ 1), 2) Jurusan Pendidikan Seni Pertunjukan, Universitas PGRI Palembang \\ Email : ilhaque@gmail.com ${ }^{l)}$, vennyfadillah@gmail.com ${ }^{2}$,
}

\begin{abstract}
The implementation of Field Experience Practices (PPL) is a routine activity carried out every year by the Teacher Training and Education Faculty (FKIP), improving the quality of graduates and as a pre-condition for student teacher candidates for the school environment and gaining teaching experience. In contrast to the previous PPL implementation, the Covid-19 pandemic phenomenon occurred to coincide with the implementation of PPL in 2020. This unusual condition requires executors and other related parties to be wise in responding to this situation. The head of this research aims to find out information and describe the learning of cultural arts with the main subjects of fine arts, music and dance at SMP 35 Negeri Palembang by students participating in PPL during the Covid-19 pandemic, starting from the preparation of learning tools, learning implementation systems and techniques. evaluation. Qualitative is used to answer research questions, the policy of the principal who continues to carry out health protocols according to both central and local government regulations, student PPL participants continue to carry out learning using the application of their choice.
\end{abstract}

Key word: Learning of Cultural Arts, Practical Field Experience (PPL),Covid-19 Pandemic

\begin{abstract}
ABSTRAK
Pelaksanaan Praktik Pengalaman Lapangan (PPL) merupakan suatu kegiatan rutin yang dilaksanakan setiap tahun oleh Fakultas Keguruan dan Ilmu Pendidikan (FKIP), meningkatkan mutu lulusan serta sebagai pra-kondisi mahasiswa calon guru mengenali lingkungan sekolah dan mendapatkan pengalaman mengajar. Berbeda dengan pelaksanaan PPL sebelumnya, fenomena pandemi Covid-19 terjadi bertepatan dengan pelaksanaan PPL tahun 2020. Kondisi yang tidak biasa tersebut menuntut pihak pelaksana dan pihak terkait lainnya untuk bijaksana menyikapi keadaan tersebut. Kepala Penelitian ini bertujuan untuk menggali informasi dan mendeskripsikan pembelajaran seni budaya dengan materi pokok seni rupa, seni musik dan seni tari di sekolah SMP 35 Negeri Palembang oleh mahasiswa peserta PPL masa pandemi covid-19, mulai dari persiapan perangkat pembelajaran, sistem pelaksanaan pembelajaran dan teknik evaluasi. Pendekatan kualitatif digunakan untuk menjawab pertanyaan penelitian, kebijakan kepala sekolah yang tetap menjalankan protokol kesehatan sesuai aturan pemerintah baik pusat maupun daerah, mahasiswa peserta PPL tetap melaksanakan pembelajaran secara daring menggunakan aplikasi pilihan masing-masing.
\end{abstract}

Kata Kunci : Pembelajaran Seni Budaya, Praktik Pengalaman Lapangan (PPL), Pandemi Covid-19 


\section{Pendahuluan}

Peningkatan mutu lulusan merupakan suatu pertimbangan penting Universitas PGRI Palembang, sebagai salah satu perguruan tinggi swasta terbesar di Sumatera Selatan, Universitas PGRI Palembang terus berupaya melakukan pengembangan dari berbagai aspek demi meningkatkan kualitas pendidikan. Untuk mewujudkan tujuan tersebut, maka Fakultas Keguruan dan Ilmu Pendidikan (FKIP) Universitas PGRI Palembang menyelenggarakan kegiatan Praktik Pengalaman Lapangan (PPL), yaitu suatu kegiatan intrakurikuler pembentukan profesi keguruan, maupun profesi kependidikan lain yang harus diikuti oleh mahasiswa calon guru/pendidik secara langsung di sekolah.

Kegiatan PPL tersebut memfasilitasi mahasiswa untuk melakukan praktik mengajar di sekolah, di samping itu sebagai calon guru/pendidik, mahasiswa peserta PPL mendapat kesempatan berlatih dan mengikuti dinamika kehidupan di sekolah yang sesungguhnya agar menjadi tenaga pendidik handal yang memiliki kecakapan profesi sesuai dengan standar pendidikan nasional, bahwa seorang guru setidaknya harus memiliki kemampuan mengelola pembelajaran (pedagogi), kemantapan kepribadian, kemampuan penguasaan materi (profesional) dan kemampuan sosial sebagai bagian dari masyarakat (sosial).

Fakultas Keguruan dan Ilmu Pendidikan (FKIP) Universitas PGRI Palembang Sebagai pelaksana kegiatan Praktik Pengalaman Lapangan (PPL) telah menjalin kerjasama dengan sekolah-sekolah dari berbagai tingkat pendidikan yang ada di Kota Palembang. Salah satu sekolah mitra penempatan mahasiswa peserta Praktik Pengalaman Lapangan (PPL) adalah SMP 35 Negeri Palembang. Sebanyak 16 (enam belas) orang mahasiswa dari berbagai program studi mengikuti kegiatan PPL di sekolah ini. Sebanyak 3 (tiga) orang peserta berasal dari program studi (Prodi) seni pertunjukan yang mana aktifitas pembelajarannya identik dengan kegiatan praktik kesenian.

Sementara itu, pelaksanaan PPL tahun 2020 ini sangat berbeda karena harus dilakukan secara virtual akibat situasi Pandemi Covid-19 yang terjadi. Semua kegiatan harus mengikuti protokol kesehatan yang telah ditetapkan oleh pemerintah, seperti yang di sebutkan oleh Wardiah (Pengantar, 2020:ii) bahwa.

"Tahun 2020 ini pelaksanaan PPL secara virtual merupakan konsekuensi Pandemi yang saat ini sedang melanda. Kami berusaha semaksimal mungkin untuk senantiasa mengakomodir kebutuhan para stakeholder yang terlibat dalam pelaksanaan PPL ini dengan tetap mengacu pada protokol kesehatan yang telah ditetapkan oleh pemerintah".

Situasi Pandemi covid-19 telah merobah berbagai aspek kehidupan masyarakat, melalui pembatasan sosial (social distancing) maupun kebijakan lain yang harus mengikuti protokol kesehatan, tentu berpengaruh terhadap dunia pendidikan. Terkait dengan mekanisme pelaksanaan PPL di sekolah mitra diatur sesuai kebijakan masing-masing sekolah. Dengan demikian, Yenny Fadhilah sebagai Kepala sekolah SMP 35 Negeri Palembang juga merespon pelaksanaan PPL pada masa Pandemi covid-19 dengan berbagai kebijakan yang tetap mengacu pada protokol kesehatan, mulai dari penyerahan mahasiswa peserta PPL, kebijakan kegiatan akademis peserta PPL, fasilitas ruangan khusus bagi mahasiswa peserta PPL, teknis penilaian mahasiswa peserta oleh guru pamong dan dosen pembimbing.

Kemunculan corona virus disease- 19 atau lebih populer dengan sebutan Covid-19 melanda seluruh dunia dan berdampak pada hampir seluruh aspek kehidupan tak terkecuali aspek pendidikan. Aktivitas pendidikan konvensional yang biasanya terjadi di ruang kelas (onsite) berhadapan secara langsung antara pendididk dengan peserta didik tiba-tiba harus dilaksanakan secara daring (online) melalui layar, siap atau tidak, demi menghambat perkembangan virus mematikan tersebut pemerintah memberlakukan social distancing (pembatasan sosial) dan harus menjaga jarak fisik (physical distancing).

Lembaga pendidikan merespon kondisi Pandemi tersebut dengan kebijakan belajar dari rumah (study from home) dengan metode pelaksanaan masing-masing sesuai dengan kondisi lembaga yang bersangkutan. Semua pihak berupaya semaksimal mungkin agar proses akademik berjalan optimal, begitu juga dengan pelaksanaan Praktik Pengalaman Lapangan (PPL) Universitas PGRI Palembang di SMP 35 Negri Palembang.

Bagi mahasiswa peserta PPL, khususnya mahasiswa prodi seni pertunjukan, keadaan demikian tentu menjadi suatu kendala dalam proses belajar mengajar seni budaya (kesenian), begitu juga dengan siswa yang akan menerima pelajaran. Sebab, sesuai dengan silabus semester ganjil tahun ajaran 2020/2021 kompetensi seni yang diajarkan oleh mahasiswa peserta PPL terdiri dari seni rupa, musik dan tari masing-masing 3 (tiga) jam pelajaran.

Berangkat dari latar belakang tersebut, kiranya perlu dilakukan penelitian, dengan demikian maka ditentukan rumusan masalah pada penelitian ini adalah "Bagaimana Pembelajaran Seni Budaya Pada Pelaksanaan PPL Masa Pandemi Covid-19 di Sekolah SMP 35 Negeri Palembang."

Tujuan penelitian ini untuk mengetahui pembelajaran seni budaya khususnya masa pandemi covid-19 pada pelaksanaan PPL di SMP 35 Negeri Palembang. Kiranya akan berguna sebagai bahan pertimbangan pada pelaksanaan PPL berikutnya baik bagi Universitas PGRI Palembang, mahasiswa Peserta PPL terutama dari prodi seni pertunjukan sekolah mitra maupun dosen pembimbing.

Seperti yang di sebutkan oleh Sugiyono (2014:62) bahwa tujuan utama penelitian adalah mendapatkan data. Oleh sebab itu, pengumpulan data dianggap paling strategis dalam penelitian. Untuk kebutuhan penelitian ini, pengumpulan data dilakukan dengan mengunjungi secara langsung (sumber primer) lokasi atau tempat penelitian sesuai anjuran data yaitu di SMP 35 Negeri 
Palembang, pengumpulan data dilakukan selama pelaksanaan PPL mahasiswa universitas PGRI Palembang di sekolah tersebut mulai 25 Juli hingga 25 September 2020.

Pengumpulan data penelitian ini menggunakan teknik triangulasi, data akan didapatkan dengan berbagai cara dan dari berbagai sumber melalui observasi, wawancara, maupun dokumentasi. Tidak menutup kemungkinan data penelitian akan diambil dari sumbersumber lain yang dianggap relevan seperti buku pedoman PPL, media massa dan jurnal. Sebab triangulasi dapat diartikan sebagai penggunaan berbagai metode, jenis data, dan sumber data sebelum peneliti mengambil kesimpulan atau keputusan (Sanjaya, 2014:45).

Penelitian ini menggunakan pendekatan kualitatif. Sesuai dengan masalah yang telah dirumuskan, maka metode kualitatif dipandang relevan dengan penelitian karena situasi Pandemi covid-19 merupakan suatu fenomena yang melanda dunia saat ini. Seperti yang dijelaskan oleh Sanjaya (2013: 44) bahwa "penelitian kualitatif didasari oleh filsafat fenomenologis" suatu fenomena akan bermakna sesuai dengan kesadaran subjek yang memaknainya.

Perlu dilakukan usaha mempelajari beberapa literatur yang relevan untuk sumber referensi pada penelitian ini. Sebuah tulisan yang berjudul "Model Pengelolaan Praktik Pengalaman Lapangan pada Masa Pandemi" Mubarok (2020) tulisan tersebut dimuat dalam jurnal Kelola: Jurnal of Islamic Education Management. Mubarok berharap pelaksanaan Praktik Pengalaman Lapangan (PPL) tetap dilaksanakan meskipun pada masa pandemi covid-19. Selanjutnya ia menawarkan bentuk pengelolaan Praktik Pengalaman Lapangan (PPL), menyangkut dengan fungsi pengelolaan mencakup perencanaan, pengorganisasian, pelaksanaan dan pengawasan. Metode penelitian kualitatif yang digunakan pada tulisan tersebut menghasilkan bentuk pengelolaan praktik pengalaman lapangan di program studi PAI Sekolah Tinggi Agama Islam Sangata- Kutai Timur tidak melibatkan guru pamong pada pelaksanaannya. Tulisan tersebut relevan dengan penelitian yang akan dilaksanakan, sebab berkaitan dengan kebijakan kepala sekolah dalam melaksanakan tugas dan fungsinya sebagai pemimpin harus memiliki kemampuan perencanaan, pengorganisasian, pelaksanaan dan fungsi pengawasan agar pelaksanaan PPL dan proses belajar mengajar tetap berjalan meskipun dalam kondisi yang tidak biasa.

Berikut penelitian Ats-Tsauri dan Munastiwi (2020) menyelesaikan penelitian tentang "Strategi Kepala Madrasah dalam menentukan kebijakan pembelajaran era covid-19: Studi kasus kepala Madrasah Ibtidaiyah NW Pondok Gedang”. Dalam penelitian tersebut, Ats-Tsauri menjelaskan bahwa Kepala Sekolah Madrasah Tsanawiyah NW Pondok Gedang sebagai penentu kebijakan di sekolah memiliki strategi tertentu agar pelaksanaan pembelajaran tetap berjalan di era pandemi covid-19. Berdasarkan hasil penelitian, Ats-Tsauri menjelaskan empat poin penting strategi kepala Madrasah Ibtidaiyah NW Pondok Gedang yakni, pertama Menyusun kelompok-kelompok belajar yang dilaksanakan di luar sekolah, kemudian guru dan siswa memanfaatkan media sosial sebagai media pembelajaran, kedua memberikan pemahan kepada guru dan siswa terkait mekanisme pelaksanaan pembelajaran daring, ketiga menambah kegiatan yang sifatnya dapat dipraktikan langsung oleh siswa, keempat penilaian siswa bersifat kualitatif yaitu penilaian yang mengarah pada membangun motivasi belajar siswa. Penelitian tersebut menggunakan pendekatan kualitatif, teknik pengumpulan data penelitian dengan wawancara, observasi dan dokumentasi. Sementara analisis data menggunakan teknik reduksi dan display data kemudian menarik kesimpulan. Penelitian tersebut relevan dan sangat berguna untuk penelitian yang akan dilakukan. Terutama terkait dengan pelaksanaan pembelajaran seni budaya yang lebih dominan dengan aktifitas praktik.

Selanjutnya salah satu penelitian Dewi (2020) dengan judul Sequential Exploratory: Pembelajaran Seni Tari Bagi Calon Guru Madrasah Ibtidaiyah di Masa Pandemi Covid-19. Penelitian tersebut menggunakan pendekatan Kuantitatif untuk mendapatkan dan analisis data, kemudian pendekatan Kualitatif digunakan untuk menyajikan hasil penelitian. Dari penelitian Dewi tersebut diketahui bahwa sebagian besar calon Guru Pembelajaran Seni Tari merasa Tidak nyaman dengan pelaksanaan pembelajaran secara daring, meskipun berbagai platform bisa dimanfaatkan untuk kebutuhan pembelajaran, namun pembelajaran secara langsung lebih baik untuk pembelajaran seni tari. Penelitian tersebut sangat berguna sebagai bahan rujukan pada penelitian ini karena memiliki kemiripan dari aspek materi yang di ajarkan.

\section{Pembahasan}

Pelaksanaan Praktik Pengalaman Lapangan (PPL) mahasiswa Fakultas Keguruan dan Ilmu Pendidikan (FKIP) Universitas PGRI Palembang tahun 2020 di SMP 35 Negeri Palembang, bertepatan dengan suatu peristiwa luar biasa dimana seluruh dunia di serang oleh virus yang mematikan. Keadaan demikian mengharuskan Kepala Sekolah SMP 35 Negeri Palembang yakni Ibu Yenny Fadhilah menentukan berbagai kebijakan agar proses belajar mengajar pada pelaksanaan Praktek Pengalaman Lapangan (PPL) bisa dilaksanakan secara optimal, terutama mata pelajaran seni budaya yang lebih dominan dengan kegiatan praktik.

\section{a. Kebijakan Kepala Sekolah}

Sebelum pelaksanaan PPL di SMP 35 Negeri Palembang, kepala sekolah telah menerapkan sistem belajar dari rumah (daring). Menurut Fadhilah (Agustus, 2020) belajar dari rumah merupakan instruksi pemerintah daerah, meskipun demikian pelaksanaan teknisnya kami yang menentukan, tentu saja menyesuaikan dengan kondisi dan keadaan siswa. Sebab sebagian orang tua siswa merupakan golongan ekonomi 
rendah, bahkan ada orang tua siswa yang tidak memiliki smartphone atau terkendala dengan kuota internet.

Menyikapi kondisi demikian, selanjutnya Fadhilah (Agustus, 2020) menjelaskan bahwa pelaksanaan teknis pembelajaran masa pandemi ini diatur berdasarkan tugas masing-masing mata pelajaran. Siswa harus memiliki dua buku tulis setiap mata pelajaran. Tugas diserahkan oleh orang tua siswa sesuai dengan jadwal belajar. Ini dilakukan agar siswa tidak berkerumun dan bermain di sekolah.

Terkait dengan pelaksanaan PPL, sesuai dengan kebijakan kepala sekolah SMP 35 Negeri Palembang, peserta PPL diarahkan oleh masing-masing guru pamong untuk melanjutkan sistem belajar secara daring, kepala sekolah juga menginstruksikan kepada guru pamong untuk tetap mendampingi peserta PPL dalam melaksanakan aktivitas akademik mulai dari membuat RPP, Pelaksanaan belajar mengajar secara daring dan penilaian tugas siswa.

\section{b. Pembelajaran Masa Pandemi Covid-19}

Layaknya aktifitas belajar mengajar di sekolah formal terdiri dari guru dan siswa berada dalam satu ruangan kelas, sehingga proses transfer ilmu dapat terlaksana dengan baik. Namun akan berbeda jika pembelajaran dilakukan dalam kondisi pandemi covid-19 yang berpengaruh terhadap berbagai aktifitas kehidupan termasuk aktifitas pendidikan. Terutama pendidikan seni budaya yang sarat dengan pembelajaran praktik.

Berdasarkan data yang didapatkan, berikut adalah proses pembelajaran seni budaya di SMP 35 Negeri Palembang yang dilaksanakan oleh mahasiswa peserta PPL dari Universitas PGRI Palembang, mulai dari persiapan, pelaksanaan sampai pada teknik evaluasi siswa.

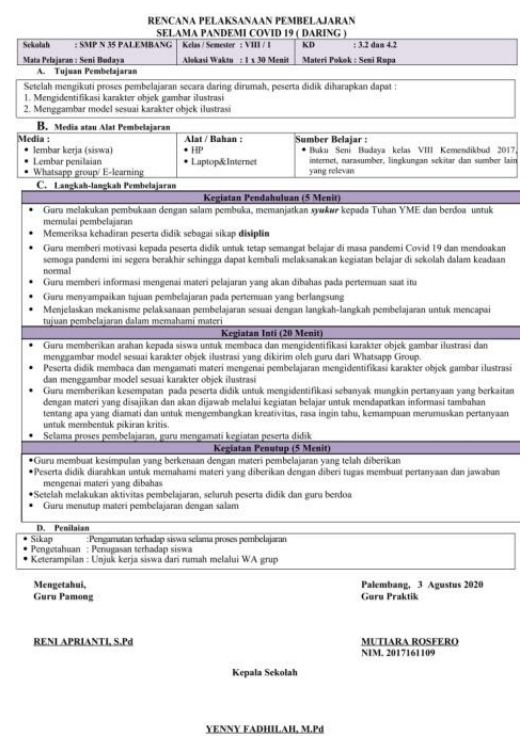

Gambar 1. Salah satu contoh RPP (Daring) materi Seni Rupa (Foto: Rosfero, 2020).
Berdasarkan dari RPP di atas, jelas disebutkan pada bagian kop (kepala) "Rencana Pelaksanaan Pembelajaran Selama Pandemi Covid-19 (daring)" tampaknya seluruh aktifitas pembelajaran dilaksanakan secara daring.

Alat yang digunakan adalah HP maupun laptop dengan memanfaatkan aplikasi Whatsapp dan you tube, serta durasi waktu untuk mata pelajaran seni budaya selama 30 menit.

\section{Pelaksanaan Pembelajaran (instruksional)}

Meskipun pembelajaran dilaksanakan secara daring, namun setiap peserta PPL diharuskan datang kesekolah setiap hari kerja seperti para guru yang lain. Sesuai dengan protokol kesehatan pembatasan sosial (social distancing) kepala sekolah SMP 35 Negeri Palembang memberikan ruang terpisah kepada peserta PPL, sebuah ruangan khusus yang difasilitasi dengan wifi agar para peserta PPL dengan mudah melaksanakan Proses Belajar Mengajar (PBM).

a. Pembelajaran Seni Rupa

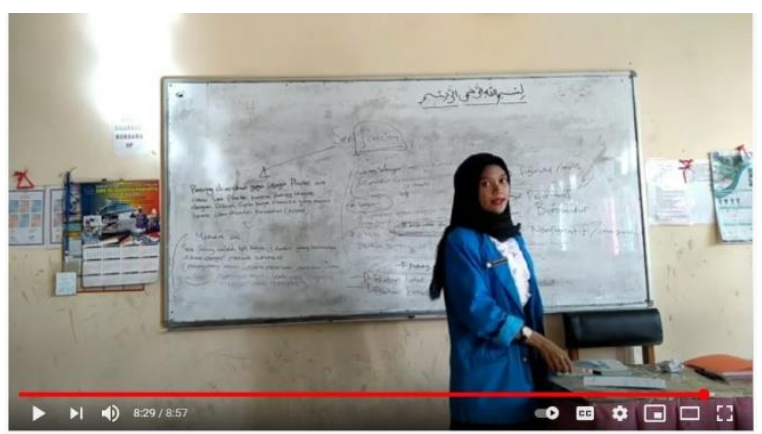

Gambar 2. Suasana belajar mengajar seni rupa secara daring melalui video you tube mahasiswa peserta PPL (Foto: Ajeng, 2020).

Pokok bahasan yang di sampaikan pada gambar (2) di atas adalah seni rupa dengan materi membuat gambar ilustrasi, durasi waktu 30 menit dikurangi 10 menit untuk pembuka dan penutup pelajaran. Artinya 20 menit adalah waktu efektif dalam satu kali pertemuan. Melalui grup whatsapp, guru memberikan arahan kepada siswa untuk membaca dan mengidentifikasi karakter objek gambar ilustrasi dan menggambar model berdasarkan karakter objek yang dikirim oleh guru melalui grup whatsapp. Sumber belajar diambil ditentukan dari buku seni budaya kelas VIII yang diterbitkan oleh kemendikbud tahun 2017 serta sumber-sumber lain yang diambil dari internet.

Setiap pembelajaran tentu dilakukan evaluasi, teknik penilaian mata pelajaran seni budaya dengan materi pokok seni rupa membuat gambar ilustrasi didasarkan kepada pengamatan siswa selama proses pembelajaran kemudian melalui tugas-tugas serta unjuk kerja siswa dari rumah yang pantau melalui grup whatsapp. 


\section{b. Pembelajaran Seni Musik}

Salah satu materi pokok mata pelajaran seni budaya yang di ajarkan oleh mahasiswa peserta PPL adalah seni musik, dengan durasi waktu selama 30 menit dan sistem pembelajaran daring memanfaatkan whatsapp grup, penjelasan mengenai teknik pengembangan ornamentasi melodis dan ritmis lagu dalam bentuk vokal solo, kemudian dilanjutkan dengan penayangan video pembelajaran vokal yang sudah di persiapkan melalui link you tube: https://youtu.be/QDikbQ6BeoE.

Siswa diberikan kesempatan untuk memberikan komentar atau respon terhadap materi yang telah diberikan. Kemudian melalui whatsapp group, guru memberikan soal uji kompetensi.

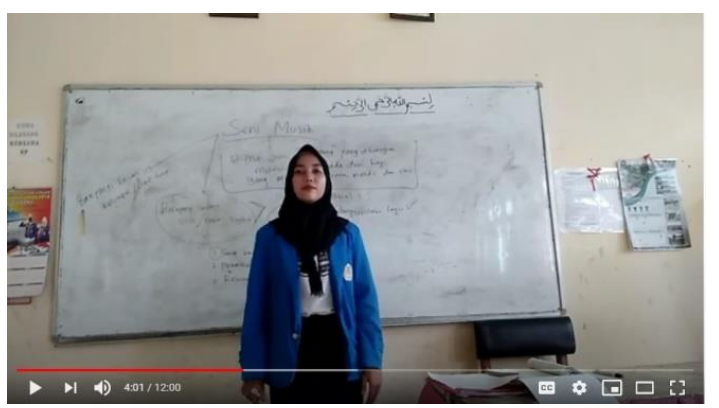

Gambar 3. Suasana belajar mengajar seni musik secara daring melalui video you tube mahasiswa peserta PPL (dok. Roenjani :2020)

Sementara sumber belajar ditentukan dari Buku Seni Budaya kelas IX Kemendikbud 2017, internet dan sumber lain yang dianggap relevan. Teknik penilaian dilakukan berdasarkan pengamatan terhadap siswa selama proses pembelajaran yakni tentang kedisiplinan dalam kehadiran dan keaktifan dalam forum kelas serta ketepatan waktu penyelesaian tugas (jika ada).

\section{c. Pembelajaran Seni Tari}

Selain seni rupa dan seni musik, mahasiswa peserta PPL juga mengajarkan materi pokok seni tari pada mata pelajaran seni budaya dengan pembahasan tari tradisional. Sumber belajar yang digunakan adalah buku seni budaya kelas VIII Kemendikbud tahun 2017 dan sumber internet, durasi waktu selama 30 menit setiap pertemuan. Sistem pembelajaran secara daring dengan menggunakan aplikasi Whatsapp dan video yang telah di siapkan dan diupload melalui Whatsapp Group.

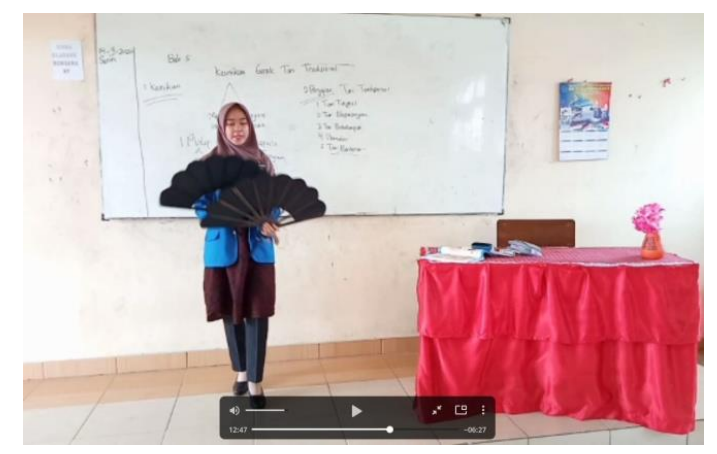

Gambar 3. Suasana belajar mengajar seni tari secara daring melalui video Whatsapp group mahasiswa peserta PPL (dok. Rosfero :2020)

Melalui video pembelajaran tari tradisional tersebut, mahasiswa PPL sebagai guru memperagakan gerakangerakan tari yang menjadi bahasan tiap pertemuan, kemudian siswa diarahkan untuk merumuskan pertanyaan dan mengembangkan kreatifitas. Kemudian teknik penilaian dilakukan berdasarkan pengamatan terhadap siswa selama proses pembelajaran, penugasan dan unjuk kerja siswa dari rumah melalui Whatsapp group.

\section{Kesimpulan}

Proses pembelajaran seni budaya mahasiswa peserta PPL di SMPN 35 Palembang pada masa pandemi Covid19 secara umum terlaksana dengan baik, tentu semua proses pelaksanaan tersebut tidak terlepas dari peran berbagai pihak baik pihak sekolah, pihak universitas dan pihak siswa. Semua bisa memaklumi kondisi yang sedang terjadi.

Mekanisme pembelajaran harus dilaksanakan secara daring (dalam jaringan), siswa tetap mengikuti pembelajaran dengan baik, tugas - tugas dikerjakan sesuai dengan perintah dan waktu yang ditentukan.

Interaksi selama proses pembelajaran seni budaya dengan materi pokok seni rupa, seni musik dan seni tari terjadi melalui aplikasi online, whatsapp group dan youtube menjadi pilihan karena dianggap lebih familiar mudah di pahami dan penggunaannya cukup praktis.

Perlu menjadi petimbangan untuk pembelajaran seni budaya materi pokok seni rupa, musik dan tari yang sarat dengan kegiatan praktek membutuhkan waktu yang lebih panjang. Sebab waktu yang tersedia setiap pertemuan hanya 30 menit dan waktu efektif hanya 20 menit untuk menyampaikan materi. Kiranya ini adalah waktu yang cukup singkat.

Di samping itu, disarankan kepada mahasiswa peserta PPL penggarapan video pembelajaran mata pelajaran seni budaya agar dibuatkan juga video detail teknik pembuatan karya seni rupa, begitu juga dengan seni musik video detail teknik vokal dan seni tari dibuat video detail tentang gerak tari yang diajarkan. Mengingat peserta didik yang masih duduk dibangku sekolah menengah pertama, tentu akan kesulitan memahami pembelajaran tanpa di imbangi dengan video detail.

\section{Daftar Pustaka}

Ats-Tsauri, Muhammad Sufyan. Munastiwi, Erni. (2020) Strategi Kepala Madrasah Dalam Menentukan Kebijakan Pembelajaran Era Covid-19: Studi Kasus Kepala Madrasah Ibtidaiyah NW Pondok Gedang. ElementerIs: Jurnal Ilmiah Pendidikan Dasar Islam, 
2 (2), 2655-6324 diakses dari http://riset.unisma.ac.id/index.php/je.

Dewi, Mutiara Sari. (2020). Sequential Exploratory: Pembelajaran Seni Tari Bagi Calon Guru Madrasah Ibtidaiyah di Masa Pandemi Covid-19. ElementerIs: Jurnal Pendidikan Dasar Islam, 2 (1), 2655-6324 diakses dari http://riset.unisma.ac.id/index.php/je

FKIP. (2020). Pedoman Pelaksanaan Praktik Pengalaman Lapangan. Palembang: Universitas PGRI Palembang.

Gischa, Serafica. (2020, Maret 18). Pandemi Apa itu?. Diakses dari. https://www.kompas.com/skola/read/2020/03/18/15 0000269/pandemi-apa-itu?/

Mubarok, Ramdanil. (2020). Model Pengelolaan Praktek Lapangan Pada Masa Pandemi. Kelola: Journal of Islamic Education Management, 2 (5), 2685-9939 diakses dari: http://ejournal.iainpalopo.ac.id/index.php/kelola

Sanjaya, Wina. 2014. Penelitian Pendidikan. Jenis, Metode dan Prosedur. Jakarta: Kencana

Sugiyono. Metode Penelitian Pendidikan Pendekatan Kuantitatif, Kualitatif, dan $R \& D$. Bandung: Alfabeta.2014. 